\title{
DNA Replication Licensing Factor MCM7
}

National Cancer Institute

\section{Source}

National Cancer Institute. DNA Replication Licensing Factor MCM7. NCI Thesaurus. Code C33912.

DNA replication licensing factor MCM7 (8719 aa, $\sim 81 \mathrm{kDa}$ ) is encoded by the human MCM7 gene. This protein plays a role in the synthesis of a single copy of a genome before mitosis. 